Nell, Ian $\mathrm{A}^{1}$

Stellenbosch University

\title{
Preaching as self-categorisation: analysing a Beyers Naudé- sermon by making use of Social Identity Theory ${ }^{2}$
}

\begin{abstract}
"Obedience to God" was the title of a sermon delivered by dr Beyers Naudé on Sunday 22 September 1963 at Aasvoëlkop Congregation of the Dutch Reformed Church in Johannesburg, South Africa. The Scripture reading was taken from Acts 5:29 which reads: "We must obey God rather than men." On that same occasion he announced his decision to accept the directorship of the Christian Institute of Southern Africa. These events introduced a new phase in the narrative of Naudé and his relationship with his people. In this article notions like self-categorisation as part of Social Identity Theory were used as heuristic tools to explore in what ways this sermon-event played a significant role in a new phase of self-definition in Naudés life story. At the same time the role of preaching as a process of social identity formation (self-categorisation) comes under the spotlight. In conclusion some pointers were given for reflection on the reformation of preaching within the context of the Twenty First Century by making use of the Confession of Belhar as a framework for interpretation.
\end{abstract}

\section{INTRODUCTION}

The title of the conference Viva Vox Evangelii: Reforming Preaching Today created an opportunity to go back in history and revisit important sermons to see how the living voice of the gospel contributed to the reforming of preaching. One of the preachers who kept the voice of the gospel alive and contributed to the reforming of preaching during the apartheid years in South Africa was the respected Dutch Reformed Church (DRC) minister and ecumenical theologian dr Beyers Naudé. Besides many other documents, articles and books, 1500 of Naudé's sermons were also preserved. ${ }^{3}$

The purpose of this contribution is to analyse one of Naudés sermons in the light of the title of the conference. He delivered this specific sermon on Sunday 22 September 1963 in the DRC Aasvoëlkop in Johannesburg, on the occasion of his resignation from the Dutch Reformed Church and the beginning of his full-time directorship at the Christian Institute. Naudé (1995:68) himself described it as a life changing moment in his career, thereby emphasising the importance of this specific sermon and moment in his life story. ${ }^{4}$

1. Associate professor in practical theology.

2. Paper delivered at the 10th biannual meeting of the Societas Homiletica, Wittenberg, Germany, 10-15 August 2012. The theme of the conference: Viva Vox Evangelii; Reforming Preaching Today.

3. Interview with two researchers at the Beyers Naudé Centre for Public Theology, prof. Robert Vosloo and dr. Murray Coetzee. The Beyers Naudé Centre for Public Theology houses Naudé's sermons, which are available for research.

4. In his own words: “Op Sondag 22 September het ek ná nagte van intense gemoedsworsteling my antwoord aan Aasvoëlkop gegee in 'n preek met die titel "Gehoorsaam aan God" (Naudé, 1995:68). 
NGTT: Oopbron - http://ngtt.journals.ac.za

After paying attention to specific aspects of the sermon, the researcher will look at the sermon through the lenses of Social Identity Theory as a heuristic instrument as he believes that this theory from social psychology can help open new perspectives on the interaction of the personal and social circumstances Naudé found himself in during that phase of his career. These circumstances were part of a process of identity formation and played an important role in keeping the voice of the gospel alive, contributing to the reforming of preaching. In the light of the results of this analysis, possible markers for the progressive reformation of preaching within a new context will be discussed in the last section of the contribution.

\section{Sermon: "Obedience to God"}

On the morning of 22 September 1963 Naudé announced his decision to accept the directorship of the Christian Institute of Southern Africa. The theme of his sermon was "Obedience to God". The scripture reading was taken from Acts 5:29 which reads: "We must obey God rather than men." Naudé's exegesis of the Bible text consisted of highlighting the roles of the different characters in the story, including that of the central character, Jesus Christ. Thereafter Naudé concluded: "The Apostles rejoiced that they were counted worthy to suffer for their Master, and they continued with their teaching - disobedient yet at the deepest level obedient, unfaithful, yet faithful at the deepest level."

He went on to explain the implications of this decision of the apostles for his own life, for the community of the DRC as well as for the ministers in the church. His prophetic words for the ministers still ring true (2005:29):

"Very many ministers are deeply concerned about the course of events in our Church. Many are concerned because it appears that the Church is not free to act solely on the authority of God's Word because of other influences and powers are playing the dominant role. Many are convinced that great changes will have to take place in our ecclesiastical and race relations on many levels. But for various reasons they suppress these convictions: the fear that if they speak, the Church will be harmed, the fear that our members are not yet ready to accept these truths, the possible repercussions in our congregations. In such a situation we are called to act with the utmost responsibility, but certainly not to remain silent. The proclamation of the truth of the Gospel cannot harm the Church of Jesus Christ! And if our members are not influenced by all sorts of powers but are enlightened fully and fearlessly as to just what the Word of God requires of all people (white as well as nonwhite), then will the Spirit of God not lead them into all truth? Why then do we fear? Has the time not arrived for us to proclaim clearly and with joy: Thus said the Lord?"

These words were uttered a mere 15 years after the Nationalist Party came to power in 1948 (where after they ruled for a further 27 years as a minority government). When one takes this into account, the prophetic quality (living voice) and implication of this uttering (reforming preaching) by Naudé are startling.

In the next section Social Identity Theory will be discussed and then used as heuristic lenses to analyse the sermon of Naudé.

5. The sermon was translated and published in The Legacy of Beyers Naudé, LD Hansen (ed.) 2005:25-29, Beyers Naudé Centre Series on Public Theology. 
NGTT Deel 54, Nommers 1 \& 2, Maart en Junie 2013

\section{Social IDENTITY THEORY}

\subsection{Introduction}

The origins of Social Identity Theory are to be found in the pioneering work of two European researchers namely Henri Tajfel and John Turner (Haslam, Reicher \& Platow, 2011:45-64). At the heart of this approach to the study of social groups we find the notion of "social identity". This refers to an individual's internalised understanding of participation in a group. "It is a sense of self associated with an awareness that one belongs to a particular social group and that this group membership is important and meaningful" (Tajfel, Turner, Austin \& Worchel, 1979:35).

It is social identity that allows human beings to refer to themselves as "we" (for example, as "believers" or as "reformed believers"). One can start the process of determining why social identity is important for this study, by asking the question: What is it that turns any collection of human beings into a social group? Why do people become part of a group?

Research in social psychology over the past three decades has shown that the answer cannot only be found and described in individualistic terms (personal advantages). Turner, Hogg, Oakes, Reicher and Wetherell (1987) for example, found that people become part of groups because the group itself matters to them; both because they have a choice to become part of it but also because they commit themselves to the group. It seems that human beings become part of a group on a personal level because they really want to and on a group level because they reckon that it is the right thing to do.

It was precisely the latter that lead Tajfel et al. (1979) to resolve the belonging of social identity to the functioning of groups. They came to the conclusion that the group is more than the sum of its parts. "Groups have higher order emergent properties and these transform the individual, while at the same time allowing individuals to engage in group processes that are capable of transforming the world" (Tajfel et al., 1979; Turner et al., 1987).

\subsection{Phases in theory forming}

According to Haslam et al. (2011:50) theory forming around social identity has developed through two phases. In the initial phase Tajfel et al. (1979:36) attempted to find a better explanation for the results of their experiment with so-called "minimal group studies". They found that when human beings accept a certain group identity as their own in terms of their own subjective self-definitions, they attempt to find the meaning and social appearance of the group in terms of comparisons between their own so-called "in-group" and relevant "out-groups". Furthermore, they tend to introduce the own group favourably by positively distinguishing it from other groups in terms of their own values. The latter is the search for the so called "positive distinctiveness".

Many factors come into play with positive distinctiveness. These include whether the "boundaries" between groups are visible and how permeable or impermeable those boundaries may be, how safe or unsafe the intergroup relationships are and what brings cognitive and social competition to the fore. This all depends on the norms and values by which the groups define their social identity.

This leads to the conclusion that there is always a connection between the nature of the group and group processes, and the social context. Also, that the meaning of social identity can shift 
NGTT: Oopbron - http://ngtt.journals.ac.za

(thus it is fluid) depending on who the group compares itself to.

This brings us to the second phase in the theory forming of social identity, namely, selfcategorisation theory.

\subsection{Self-categorisation theory}

For Turner et al. (1987:38-39), the basis of their research was simply that inviting individuals to categorise themselves as group members (thus self-definition in terms of social identity) was already enough reason for their group action. This study clearly shows that the cognitive processes of self-definition play the biggest role in group attendance. Thus we participate in group activities to the extent that it is possible for us to think of ourselves as "we" and not just "I". "Social identity is the cognitive mechanism which makes group behaviour possible."

Turner developed the self-categorisation theory with colleagues from the University of Bristol and the Australian National University (Haslam et al. 2011:52). Along with the acknowledgement of the importance of social identity theory as the basis for the action of the group, self-categorisation theory emphasises the psychological process that underlies the transition of behaviour. Transition of behaviour here refers to behaviour that is informed by a person's understanding of his or her social identity.

To express the idea that the self is no longer seen in terms of personal terms (the "I"), Turner (1987) makes use of a process known as depersonalisation. The latter is a process of selfstereotyping, through which the self is seen in terms of a category membership shared with other "in-group" members. This depersonalisation process leads to human beings not acting as unique persons towards themselves and others but as psychological representatives of the groups they belong to. Depersonalisation thus reflects a higher order, a more inclusive and more abstract level of self-categorisation. But according to Haslam et al. (2011:53), depersonalisation not only has a connection with the way in which we react to one another, but also with the way in which we act towards the world in general. Through the process of depersonalisation, the group becomes the criterion according to which we measure everything.

The norms and values that determine our actions are the norms and values of the group that we currently associate ourselves with and it varies from group to group. As I for example move between the community to which I belong and the sport club where I am a member, the values between the two differ significantly. It can also happen that I will on occasion be prepared to sacrifice myself to promote the common wellbeing of the group - like we see in times of war.

According to Hogg (2001:184), depersonalisation not necessarily means a loss of the self but rather a redefining of the self. This means that the depersonalised self is just as psychologically and morally valid as the personalised self to feel, to think and to act. But now self-esteem is determined by the values of the group, and the "self" of "self-interest" is to a greater extent stipulated by the interests of the group.

However, the self-interest of the group cannot always be defined in advance, as for some groups it may mean money or material things and for others perhaps rather respect, love and service to others. Thus, the importance of depersonalisation is of vital importance for social action and social identity, as it helps to coordinate the activities, to identify who is on which side and what goals are being pursued. 
According to Adair (2007:97), this is especially important when addressing the role of leaders in the groups, thus persons who take responsibility for the guidance and cooperation of the group. He writes: "Leadership means [...] the understanding and sharing of a common purpose - without that there can be no effective leadership." Without a shared experience of "us", no leadership or followers are possible.

Postmes, Haslam and Swaab (2005:23) give a graphic illustration of the factors involved in the formation of social identity in the following figure:

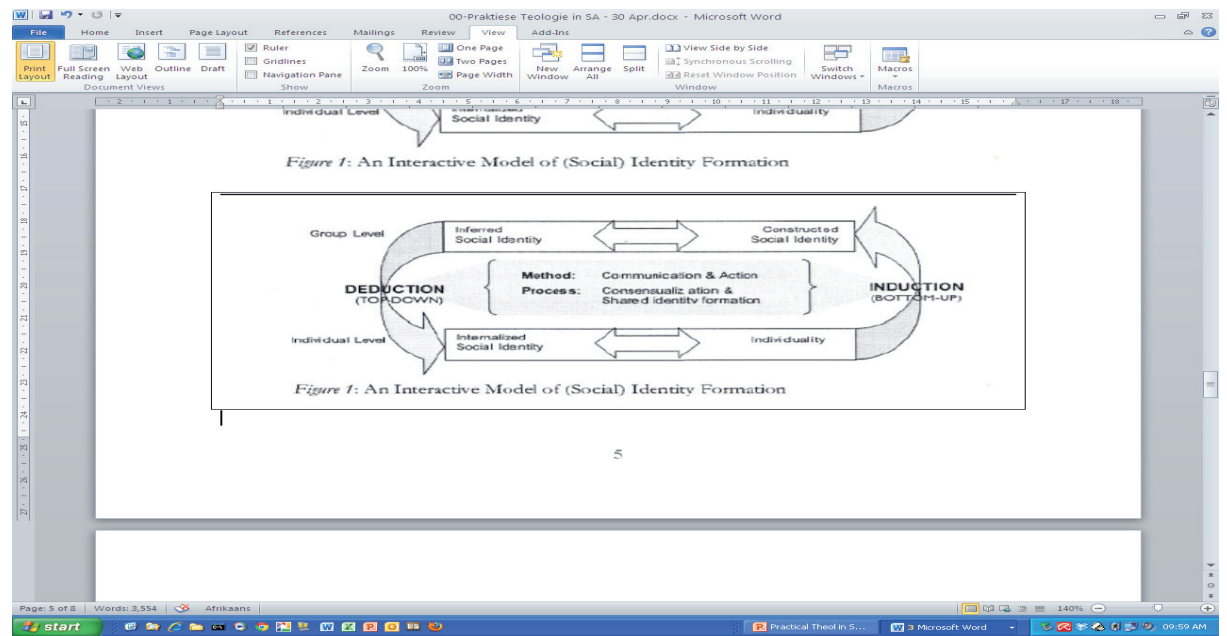

Based on historical and ideological aspects of understanding, embedded in the narrative of groups, group members make assumptions (deduction in Figure 1) about certain attributes of social identity - thus what it means to be a member of this group at this given moment. At the same time, the action or behaviour of certain individual group members can also have an impact (induction in Figure 1) on the action or the behaviour of the group - this is particularly relevant to the role of leaders in groups. It is clear that what happens on a group level and what happens on an individual level constantly influence one another, hence the description of an "interactive model" in social identity formation (Postmes et al., 2006:23).

Social Identity Theory comprises two movements: the way in which social reality forms social identities; and the way in which social identity gives form to social reality. To be more specific, Social Identity Theory is related to the way in which individuals attempt to define social identities with the goal to mobilise collective action and to ultimately be able to exercise an influence on the social reality. This leads to the argument that because definitions about identity have such important social and political consequences, leaders search for ways in which to use these definitions for their own purposes, rather than accepting it as a given. So the leader is searching for a definition of the self and the group as prototypes. Furthermore, there is a search for a definition of group boundaries to include as big a part of humanity as possible with a view to mobilisation. And lastly, there is a search for a definition of the content of group identity and suggestions about the concrete manifestation of shared beliefs and values (Haslam et al., 2011:146). 
NGTT: Oopbron - http://ngtt.journals.ac.za

Thus leaders are not just interpreters of identity for a wider public who work with a self-evident understanding of the group only, they often have to work hard to determine a specific version of identity. That is why leaders are often referred to as "entrepreneurs of identity" rather than as "interpreters of identity" (Haslam et al., 2011:146).

\section{Application of Social Identity Theory on Naudé's sermon}

In the light of the concepts from Social Identity Theory as a heuristic instrument, it is possible to make some remarks about the role of Naudé's social context, his personal story and his interpretation of that story. The focus will also be on the way that all this contributed to keeping the voice of the gospel alive and helped with the reformation of preaching.

\subsection{The formation of social identity}

We have seen that "social identity" is described as: "[...] a sense of self associated with an awareness that one belongs to a particular social group and that this group membership is important and meaningful" (Tajfel et al., 1979:35). Naudé (2005a:25) starts his sermon by describing a "group of men and women busy preaching God's name" from the Acts 5 text. This group is not viewed positively by the other groups namely the Sanhedrin and the Sadducees because they were disobedient to an order of the high priest. This group of believers disrupted the peace of Jerusalem (Acts 5:28) with the "heresy" they were preaching. Peter, as a representative of this group, talks on behalf of the group and says: "A human being should rather be loyal to God than to people!" (5:29). Peter then explains something of the history of this God with his people (5:30-39).

In the next part of the sermon, Naudé applies this to his own situation and confesses how God, through his Spirit, time and again brought him back to this text (2005a:27). Based on this text, he was persuaded that the Synod decision (of the Dutch Reformed Church) was very problematic, namely "that the God-given right and freedom of ministers and members to witness to the truth of God's Word in the spirit of the prophets and the reformers is so restricted that the minister of the Gospel in principle no longer enjoys the freedom to declare his deepest Christian convictions in the way or at the place and time given him by God to speak through his Word and Spirit" (2005a:27).

This brought Naudé to a choice (2005a:27): "Consequently the choice facing me is not primarily a choice between pastoral work and other Christian work or between the Church and Pro Veritate, or between the Church and the Institute. No, the choice goes much deeper: it is a choice between obedience in faith and subjection to the authority of the Church. And by unconditional obedience to the latter, I would save face but lose my soul."

He continues by motivating this choice: "By joining the Christian Institute, I am not leaving the Church. On the contrary, I wish, through the Institute, to serve my church and the wider ecumenical context, even if my church today does not officially see it in this light, or so desire it" (2005a:27). What is important from a social identity perspective is his reference to his Afrikanerskap: "And every true Afrikaner is deeply in sympathy with his people in this anxious time (and I associate myself with them as an Afrikaner who, just as in the past, today still wishes to serve his people with the same love and faithfulness)" (2005a:28).

In terms of Social Identity Theory, this is a deliberate move; you can even call it a deepening of social identity: not the Church or the Institution or the Nation, but obedience to the Word 
of God is of central importance here. The dialogical interaction between social and personal aspects of identity formation is at work. The latter could also be described as a "group", just like in Acts 5, namely, the group that wants to be "loyal to God". Naudé (1995:16) describes the self as part of the group (self-categorisation) that "stands with God" where the "Kingship of Jesus Christ" gets preached to all nations. It is the "living voice of the gospel" that determines identity here.

Apart from belonging to this group that "stands with God", it is also quite clear that Naudé's membership of the Christian Institute and participation in Pro Veritate provided other groups to which he belonged with their own boundaries, group definitions and underlying values. In this regard one can also see the importance for him of belonging to the Afrikaner people and serving his people albeit with the reservations he later explains (2005a:28). It is apparent that his membership of these groups greatly influenced his social identity in the sense of his awareness that he belonged to these particular social groups and that his membership of these groups was important and meaningful to him.

\subsection{A cognitive and psychological process}

Social Identity Theory furthermore makes us aware that there is a combination of cognitive and psychological processes in the formation of identity as part of this self-categorisation. In the sermon of Naudé it is obvious that his understanding of Scripture (interpretation and exegesis) played a decisive role as seen in his use of Acts 5:29 as a core text. The loyalty that is mentioned here is thus related to a deliberate decision that would ask enormous sacrifices from him. One can sense different psychological processes at work here.

What is of vital importance in this regard is the way in which he reflects on what happened to him towards the end of his career as described in the last page of his autobiography. He writes: "Thirty two years after I said farewell with such sorrow in my heart, I had the wonderful privilege to ascend that pulpit once again and preach in that church again" (1995:152, translation IAN). In his "cognitive" reflection about that day (13 August 1995), he writes about strongly charged "emotions" that find expression in embrace, joyful re-encounters, tears, excuses, amazement, joy and expectancies. One can sense his overwhelming emotional response to re-joining a group to which he previously belonged, but had been "banned" from for many years.

The remark Turner et al. (1987:21) made that "social identity is the cognitive mechanism which makes group behaviour possible" and the psychological processes underlying the transition of behaviour, interplay. The transition of behaviour in question in Naudé's conduct is transition of behaviour that is informed through his understanding of his personal identity (in Christ) to behaviour that is informed though his understanding of his social identity as part of a group of people that wants to be obedient to God. In the process we see a broadening of identity taking place through self-categorisation.

This brings us to the last two concepts of the Social Identity Theory that I would like to address in this study, namely depersonalisation and self-stereotyping.

\subsection{A process of depersonalisation and self-stereotyping}

As discussed previously, where the self is no longer seen only in personal terms (the "I"), Turner (1987) refers to a process known as depersonalisation. The latter is also a process of self-stereotyping where the self is seen in terms of a category membership shared with other 
NGTT: Oopbron - http://ngtt.journals.ac.za

"in-group" members. Hogg (2001:184) takes the argument a step further - according to him depersonalisation does not necessarily mean a loss of the self but a redefining of the self. This means the depersonalised self is just as psychologically and morally valid and meaningful as the personalised self. But now the self-image is determined by the values of the group, and the "self" of "self-interest" is stipulated through defining these values.

In answer to the question: "With whom are we in solidarity?" Taljaard (2006:98) demonstrates how Naudé lived in solidarity with the poor and the oppressed and how, according to notions of social identity, he redefined the "self" through depersonalisation and self-stereotyping. She motivates her argument: "The Afrikaner community has often been described as a pietistic community. The inherent danger of such an identity is that, in the extreme, it can focus too strongly on the salvation of the individual soul and can give very little, if any, attention to the broader context of relationships with others."

This of course is based on what Luther in Concerning Christian Liberty (1910:353) describes as our "human participation in Christ" and where he emphasizes that salvation stands apart from any human merit, and also argues against a narrow understanding of salvation as only the redemption of souls. Naudé links his argument to this broad (social) understanding of salvation and it becomes clear how this leads to a redefining of the self, where his self-image is determined by who he is "in Christ" and thus by the values of the group that wants to be obedient to Christ. From a theological perspective all of this contributes to the description of his ministry as a "prophetic ministry" in the true sense of the word. ${ }^{6}$

I want to conclude with some thoughts on the importance of Naudés prophetic sermon as living voice of the gospel that can also inspire the reformation of preaching in the future. For this purpose I want to make use of the structure of the Confession of Belhar to show how his sermon focuses on unity, reconciliation and justice. This demonstrates that the sermon is not only important in terms of social identity formation, but also that his preaching is indeed "prophetic preaching" contributing to social transformation. ${ }^{7}$

\section{Preaching with Beyers Naudé in the words of Belhar}

Social Identity Theory has made us aware of the importance of the social context in the formation of identity. The social context in the time of Naudé was one of apartheid that gave impetus to a redefining of the self. In the meantime this social context has changed significantly. I believe Naudé's prophetic preaching in the light of the Confession of Belhar provides a framework of interpretation for the on-going reformation of preaching. In following Taljaard's argument (2006:91-104), I want to look at the future reformation of preaching in terms of three questions:

\subsection{What is it that we resist? Preaching about unity}

6. Brueggemann (1978:13) defines prophetic ministry as follows: "This I contend that prophetic ministry has to do not primarily with addressing specific public crises but with addressing, in season and out of season, the dominant crisis that is enduring and resilient, of having our alternative vocation (as Christians) co-opted and domesticated."

7. Tubbs Tisdale (2010:9-10) describes seven hallmarks of prophetic preaching inter alia that it "is rooted in the biblical witness, counter cultural and challenges the status quo, concerned with the evils and shortcomings of the present social order, offers hope of a new day to come and the promise of liberation to God's oppressed people, incites courage in its hearers and empowers them to work to change the social order, a passion for justice in the world $[\ldots]$ ". 
In the case of Naudé, his resistance was to a false gospel where he specifically warned the Dutch Reformed Church that its interpretation of Scripture was erroneous and therefore a heresy. From the perspective of Social Identity Theory, it is important to understand that this interpretation linked the Biblical theme of a "chosen nation" to a specific ethnic group, namely the Afrikaner, and thus not to the whole family in Christ (Naudé, 2005b:57-59).

It is clear that an ideology of exclusion was at work here. According to Taljaard (2006:93), the collective identity here is based on an anthropologist understanding of race and thus not on believer's identity in Christ. In this identity group the members are loyal to each other and see outsiders (out-group) as a threat. ${ }^{8}$

"Resistance" in our current circumstances in South Africa can still be related to the way in which processes of group formation daily contribute to the exclusion of people based on race, class, gender or whatever distinctions we want to use. In a recent investigation by Cilliers \& Nell (2011), they demonstrate in what ways new processes of "enclavement" are taking place in the Dutch Reformed Church. It is especially noticeable in the three concepts of stabilization, emigration and separation. All three unravel the notion of "enclavement" and all of them are directly opposed to the quest for unity. ${ }^{9}$

Thus Naudé's sermon (and many of his other writings) is in line with the need for prophetic preaching on the unity of the church and is still very relevant for the reformation of preaching. The incorporation of a new ethos and structure in society asks for on-going attention to new attitudes and persuasions in both church and society. Social Identity Theory makes preachers aware of the danger of an identity where the interests of one group have priority and where we ultimately obey people rather than God. A recent investigation by the Institute of Justice and Reconciliation known as The Transformation Audit proves this point. ${ }^{10}$

Preaching on the unity of the church ought to be high on the agenda of the reformation of preaching. But this kind of preaching won't have a significant impact if it is not accompanied by a change in attitudes and specifically a conversion of underlying prejudices, normally starting in the preacher's own heart and life. This must also include endeavours for structural unity and active involvement in the unity processes of the family of churches to which Naudé belonged.

\subsection{With whom are we in solidarity? Preaching on reconciliation}

Beyers Naudé was in solidarity with the "other" brothers and sisters in Christ who were not part of the Afrikaner people and who formed part of the oppressed and marginalised. In this deed

8. In Naudé's own words (2005b:59): "I would like to mention in explaining the Afrikaner's traditional attitude to race is fear $[\ldots]$ for the ordinary Afrikaner his traditional enemy always had a black face or included one - and it is this fear which determined so much of his attitude and policy towards his nonwhite neighbour in this country."

9. Cilliers \& Nell (2011) came to the following conclusion: "We will have to move beyond denominationalism, if we hope to have any impact on society. We will have to revisit the 'hermeneutical space of the ecumenical church' in order to address societal ills in our country. For it is exactly within this hermeneutical space that we may discover not a self-destructive 'stability', but rather our true identity; not a misleading introversion, but rather vocation (to help transform society); not stigmatisation of, and separation from, the other, but rather the experience of facing the other and, in doing so, facing ourselves - and in the end, hopefully, the Other. It seems as if the 'safest' haven indeed lies outside 'our' haven."

10. Hofmeyer, J (ed.) 2009. Recession and Recovery. 2009 Transformation Audit. Institute for Justice and Reconciliation. Cape Town. 
NGTT: Oopbron - http://ngtt.journals.ac.za

of solidarity we find a broadening of his identity to that of an ecumenical identity. In terms of Social Identity Theory it also served as an enrichment of his life and theological thinking and led to a new self-definition. ${ }^{11}$

According to Taljaard (2006:94), they "with whom" we are in solidarity do have important implications in answer to the question of what the face of the God we are seeking, looks like. The identity of those "with whom" we are in solidarity serves as a challenge to our identity in Christ; a notion we find prominent in Naudé's sermon with its emphasis on obedience. Once again Social Identity Theory helps us with the notions of self-categorization and selfstereotyping to find clarity about the "with whom" we are in solidarity.

The third article of the Belhar Confession is about reconciliation, teaching us that it is only through reconciliation in Christ that it is possible for us to live in solidarity with other people. Here we once again find a redefinition of identity in terms of embracing the other, challenging our notions of identity. "Through Christ's reconciliatory act on our behalf, we are able to learn to confess our guilt, to ask, receive and grant forgiveness and grow into a deeper understanding of living together as brothers and sisters in Him" (Taljaard, 2006:99).

Preaching on reconciliation as part of the reforming of preaching helps us to reject any form of discrimination that obstructs the experience of Christ's reconciling act. In this regard the third article of the Confession of Belhar also challenges us to broaden our sense of identity in Christ and compels us to take our relations with "the other" very seriously.

\subsection{What do we hope for? Preaching on justice}

It is no coincidence that Beyers Naudé named his autobiography My land van hoop (My country of hope). With this title he provided a clue to his deepest persuasion namely that through the power and grace of the living God change in church and society is indeed possible and worthwhile struggling for. With these convictions he not only constructs the argument for a new social order but he also challenges all South Africans to imagine an alternative and better South Africa and to start to work towards accomplishing that dream.

The content of this hope was a hope built on justice for all people living in this country and all over the world. He writes: "Because this earth is God's earth, such rights must be accorded to all God's children everywhere on this globe" (Naudé, 2005c:115). In this regard Naudé was not only interested in an eschatological hope at the end of history but in God's involvement in the here and now of our everyday existence.

The fourth article of the Confession of Belhar encourages us to keep our faith alive through our preaching by reminding the faithful that this God is in a unique way the God of the poor and the marginalised. It is for this reason that the Confession rejects all injustice and specifically any ideology that defends injustice on Biblical principles.

It is also in this regard that preaching on hope and justice is in essence prophetic preaching.

11. "While most of the Western nations were experiencing the changes inherent in situations of increased communications, of rapid social and economic change, causing violent spiritual and intellectual upheaval, the Afrikaner community, through its secluded and often self-imposed isolation, was largely unaware of all these forces which were changing the outlook and relations of millions of people, including the relations between white and non-white" (Naudé, 2005b:59). 
Tubbs-Tisdale (2010:10) summarises it as follows: "Prophetic preaching offers hope for a new day to come and the promise of liberation to God's oppressed people. Prophetic preaching incites courage in its hearers and empowers them to work to change the social order."

\section{Conclusion}

In my argument I tried to show how the living voice (viva vox) of the gospel as part of the ongoing reformation of preaching found a comprehensive example in the life, work and preaching of dr. Beyers Naudé. I demonstrated that notions such as self-categorisation, depersonalisation and self-stereotyping are useful heuristic instruments from a social psychology perspective, and more specifically Social Identity Theory to illustrate in what ways Naudé reached a new self-definition in the light of his difficult circumstances during the time of apartheid.

The analysis of his sermon on Acts 5:29 further exposed the underlying conviction of Naudé's reformed roots. It was his emphasis on the Sola Scriptura of the Reformation that resulted in his persuasion that "we must obey God rather than men". Again the lenses of Social Identity Theory helped us to develop new perspectives for the reformation of preaching by reflecting on group norms and values.

Lastly, we saw how the Confession of Belhar can play a prophetic role to keep the living voice of the gospel on the track of reformed preaching by asking attention for preaching on the unity of the church, reconciliation amongst people and seeking justice for all people.

In 2013 it will be 50 years since Naudé preached his sermon from Acts 5:29. Half a century has passed and one is amazed by its continued relevance, not only of the words of this sermon, but also of the way in which the act of preaching is still reforming and keeping alive the voice of the gospel with an enduring influence on our social identity.

\section{BIBLIOGRAPHY}

Adair, J. 2007. Leadership for innovation: How to organize team creativity and harvest ideas. London: Kogan Page.

Brueggemann, W. 1978. Prophetic imagination. Philadelphia, PA: Fortress.

Cilliers, J.H \& Nell. I.A. 2011. "Within the enclave" - Profiling South African social and religious developments since 1994. Verbum et Ecclesia, 32 (2011) 1, 1-7.

Hansen, L. (ed.) 2005. The legacy of Beyers Naudé: Beyers Naudé Centre Series on Public Theology Volume 1. Stellenbosch: SUN Press.

Hansen, L. \& Vosloo, R. (eds.) 2006. Oom Bey for the future: Engaging the witness of Beyers Naudé: Beyers Naudé Centre Series on Public Theology Volume 2. Stellenbosch: SUN Press.

Haslam, S.A., Reicher, S. \& Platow, M. 2011. The new psychology of leadership: Identity, influence, and power. New York, NY: Psychology Press.

Hofmeyer, J. (ed.) 2009. Recession and recovery: 2009 Transformation Audit. Cape Town: Institute for Justice and Reconciliation.

Hogg, M.A. 2001. A social identity theory of leadership. Personality and Social Psychology Review, 5 (2001) 3, 184-195.

Luther, M. 1910. "Ninety-five theses: address to the German Nobility concerning Christian liberty". In The prince, by Niccolo Machiavelli, Utopia, by Sir Thomas More, Ninety-five theses: address to the German nobility concerning Christian Liberty, by Martin Luther. The Harvard Classics, Vol. 36. P.F. Collier \& Son, New York, pp. 353-397.

Naudé, C.F.B. 1995. My land van hoop: Die lewe van Beyers Naudé. Pretoria: Human \& Rousseau.

Naudé, C.F.B. 2005a. "Obedience to God," In Hansen, L.D. (ed.) 2005, The legacy of Beyers Naudé, Stellenbosch: SUN Press, pp. 25-30. 
NGTT: Oopbron - http://ngtt.journals.ac.za

Naudé, C.F.B. 2005b. “The Africaner and race relations," In Hansen, L.D. (ed.), The legacy of Beyers Naudé, Stellenbosch: SUN Press, pp. 55-62.

Naudé, C.F.B. 2005c. "Christian involvement in the struggle for human rights and justice," In Hansen, L.D. (ed.), The legacy of Beyers Naudé, Stellenbosch: SUN Press, pp. 111-116.

Postmes, T., Haslam, S.A. \& Swaab, R.I. 2005. Social influence in small groups: An interactive model of social identity formation. European Review of Social Psychology, 16 (2005) 1, 1-42.

Tajfel, H., Turner, J., Austin, W.G. \& Worchel, S. 1979. The social psychology of intergroup relations. An integrative theory of intergroup conflict, pp. 33-47.

Taljaard, A. 2006. The Belhar Confession: Embodying the future in the light of the witness of oom Bey. In Hansen \& Vosloo (eds.), Oom Bey for the future: Engaging the witness of Beyers Naudé, vol. 2, pp. 91104.

Tisdale, L.T. 2010. Prophetic preaching: A pastoral approach. Louisville, KY: Westminster John Knox.

Turner, J.C., Hogg, M.A., Oakes, P.J., Reicher, S.D. \& Wetherell, M.S. 1987. Rediscovering the social group: A self-categorization theory. Oxford: Basil Blackwell.

\section{KEY WORDS}

Leadership

preaching

social identity

self-categorization

Beyers Naudé

\section{TREFWOORDE}

Leierskap

prediking

sosiale identiteit

selfkategorisering

Beyers Naudé

\section{Contact Details/Kontakbesonderhede}

Ian A Nell

Associate Professor in Practical Theology

Faculty of Theology, Stellenbosch University

South Africa

ianell@sun.ac.za

021-808-9094 